\title{
Hypothermic Neuroprotection
}

\author{
A.J. Gunn* and M. Thoresen ${ }^{\dagger}$ \\ *Dept of Physiology, The University of Auckland, New Zealand; ${ }^{\dagger}$ University of Bristol, St Michaels Hospital, \\ Child Health, level D, Southwell Street BS2 8EG, Bristol, UK
}

\begin{abstract}
Summary: The possibility that hypothermia during or after resuscitation from asphyxia at birth, or cardiac arrest in adults, might reduce evolving damage has tantalized clinicians for a very long time. It is now known that severe hypoxia-ischemia may not necessarily cause immediate cell death, but can precipitate a complex biochemical cascade leading to the delayed neuronal loss. Clinically and experimentally, the key phases of injury include a latent phase after reperfusion, with initial recovery of cerebral energy metabolism but EEG suppression, followed by a secondary phase characterized by accumulation of cytotoxins, seizures, cytotoxic edema, and failure of cerebral oxidative metabolism starting 6 to $15 \mathrm{~h}$ post insult. Although many of the secondary processes can be injurious, they appear to be primarily epiphenomena of the 'execution' phase of cell death. Studies designed around this conceptual framework have
\end{abstract}

shown that moderate cerebral hypothermia initiated as early as possible before the onset of secondary deterioration, and continued for a sufficient duration in relation to the severity of the cerebral injury, has been associated with potent, long-lasting neuroprotection in both adult and perinatal species. Two large controlled trials, one of head cooling with mild hypothermia, and one of moderate whole body cooling have demonstrated that post resuscitation cooling is generally safe in intensive care, and reduces death or disability at 18 months of age after neonatal encephalopathy. These studies, however, show that only a subset of babies seemed to benefit. The challenge for the future is to find ways of improving the effectiveness of treatment. Key Words: Hypothermia, induced, hypoxic-ischemic encephalopathy, hypoxia.

\section{INTRODUCTION}

Moderate to severe hypoxic-ischemic encephalopathy (HIE) continues to be an important cause of acute neurologic injury at birth, occurring in 2 to 3 cases per 1000 term live births. ${ }^{1}$ The possibility that mild cooling might improve recovery from HIE is a 'dream revisited'. John Floyer suggested over 300 years ago that it might be beneficial for babies to get a little cold after birth. ${ }^{2}$ As recently noted, ${ }^{3}$ it was observed in antiquity that exposed babies could remain viable for prolonged periods, and packing in ice and snow was advocated for the wounded. ${ }^{4}$ Napoleon's Surgeon General, Baron Larrey, ${ }^{5}$ reported that injured soldiers died more rapidly if they were kept warm by being put closer to a fire.

Modern clinical interest in hypothermia began in the 1930s and 1940s with reports of successful resuscitation of hypothermic drowning victims, even after prolonged periods of asphyxia. In the 1940s Temple Fay reported

Correspondence to: Dr Alistair Jan Gunn, Depts of Physiology and Paediatrics, Faculty of Medical and Health Sciences, The University of Auckland Private Bag 92019, Auckland, New Zealand Fax: [64](9) 3737497. E-mail: aj.gunn@auckland.ac.nz treating patients with severe head injury and intracerebral aneurysms with hypothermia induced by cold baths and by opening the windows in winter. ${ }^{6}$ Experimentally, moderate hypothermia improved neurological recovery in dogs exposed to focal brain ischemia and injury. ${ }^{7,8}$ Similarly, hypothermia in perinatal rodents greatly extended the 'time to last gasp' during hypoxia and improved subsequent functional outcome. ${ }^{9}$

In retrospect, these experimental studies addressed the effect of cooling during severe hypoxia, which has now been extensively proven to be associated with potent, dose-related, long-lasting neuroprotection. ${ }^{10}$ The real clinical issue, of course, was and is whether cooling after resuscitation from asphyxial injury is beneficial. Although the studies described above had not addressed this question, these and similar findings led to several uncontrolled case series in the 1950s and 1960s in which infants not breathing spontaneously at five minutes after birth were immersed in cold water until respiration resumed and then allowed to spontaneously rewarm. ${ }^{11-14}$ Subsequently at least one study suggested that cooling could be combined with positive pressure ventilation. ${ }^{15}$ Although outcomes after cooling at birth were said to be 
better than for historical controls, ${ }^{14}$ this experimental treatment was overtaken by the recognition that even mild hypothermia is associated with increased oxygen requirements and more importantly, greater mortality in premature newborns $(<1500 \mathrm{~g}),{ }^{16}$ and the disappointing outcomes of delayed induced cooling after near-drowning. ${ }^{17}$

The present review will describe subsequent experimental work that provided a theoretical basis for treatment after severe hypoxia-ischemia, examine recent clinical studies that demonstrate that delayed hypothermia can improve recovery in infants with acute HIE, and then highlight unanswered issues surrounding the clinical use of hypothermia.

\section{PATHOPHYSIOLOGICAL PHASES OF CEREBRAL INJURY}

\section{Delayed failure of oxidative metabolism}

The seminal observation derived from both experimental and clinical observations was that HIE is not a single 'event' but is rather an evolving process. Although neurons may die during the actual ischemic or asphyxial event (primary cell death), many neurons initially recover at least partially from the primary insult, only to die many hours, or even days later (secondary or delayed cell death). Using magnetic resonance spectroscopy, Wyatt and co-workers showed that infants with evidence of moderate to severe asphyxia often have normal cerebral oxidative metabolism shortly after birth, but many then went on to develop delayed energy failure 6 to 15 hours later. ${ }^{18,19}$ Those infants who did not show even transient recovery had a very high mortality. In survivors, the degree of secondary energy failure after 24 to 48 hours was closely associated with neurodevelopmental outcome at 18 months and 4 years of age. ${ }^{20}$ An identical pattern of initial recovery of cerebral oxidative metabolism followed by secondary energy failure was seen after hypoxia-ischemia in the piglet ${ }^{21}$ and again closely correlated with the severity of cell death in the cortical area that was examined. ${ }^{22}$

It is this delay that has raised the tantalizing possibility that asphyxial cell death could be prevented even if treatment could not start until well after reperfusion.

\section{Characterizing the phases of injury}

Subsequent studies have described the phases associated with evolving neural injury in more detail as illustrated by figure 1 . The hypoxia-ischemia event is the primary phase of cell injury. During this phase there is rapid depletion of high energy metabolites, leading to progressive hypoxic depolarization of cells, with severe cytotoxic edema (cell swelling), excessive intracellular accumulation of calcium, and extracellular accumulation of excitatory amino acids (EAAs) due to both failure of

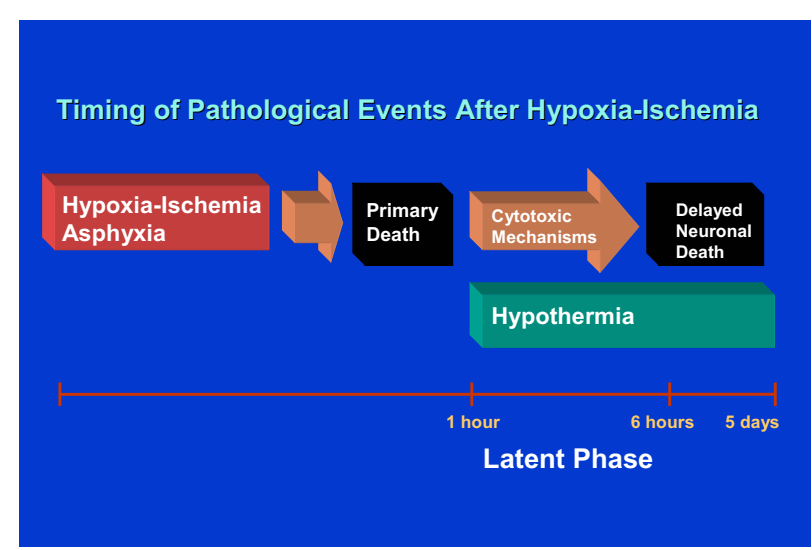

FIG. 1. Flow diagram illustrating the relationship between the phases of cerebral injury after a severe reversible hypoxic-ischemic insult. During reperfusion after the insult, there is a period of approximately 30 to 60 minutes during which cellular energy metabolism is restored, with progressive resolution of the acute cell swelling secondary to hypoxic-depolarization. This is followed by a latent phase. During this phase the intracytoplasmic components of apoptosis are activated, and the early inflammatory reaction is initiated, with induction of cytokines. This may be followed by secondary deterioration leading to ultimate delayed neuronal death after 3 days. As indicated by the bar, treatment with cerebral hypothermia needs to be initiated in the latent phase before the onset of secondary deterioration, and then continued for over 48 hours for long lasting neuroprotection.

reuptake and excessive release. ${ }^{23}$ Following return of cerebral circulation and / or oxygenation, after the end of the insult, the initial hypoxia-induced cytotoxic edema and accumulation of EAAs typically resolve over approximately 30 to 60 minutes, ${ }^{24,25}$ with at least partial recovery of cerebral oxidative metabolism, in a 'latent' phase. However, cerebral oxidative metabolism may then secondarily deteriorate many hours later (approximately 6 to $15 \mathrm{~h}$ ), in a phase that may extend over many days. ${ }^{19,21}$ At term equivalent, this secondary deterioration is often marked by the onset of seizures (figure 2), ${ }^{26,27}$ secondary cytotoxic edema, ${ }^{24}$ accumulation of excitotoxins, ${ }^{23}$ failure of cerebral mitochondrial activity $^{21}$ and ultimately, cell death. ${ }^{27,28}$

Surprisingly, although there are extensive data describing the timing and development of the delayed failure of mitochondrial oxidative metabolism after acute insults, its precise pathogenic significance remains highly controversial. For example, there is a close correlation between histological loss of the key mitochondrial cytochromes and neuronal loss, ${ }^{29-31}$ and between the timing of loss of cytochrome activity after severe anoxia in the cat and subsequent delayed onset of neurological deterioration. ${ }^{32}$ Taken with in vitro evidence that the increase in intracellular calcium levels during hypoxia/reoxygenation triggers subsequent delayed functional impairment and morphological disintegration of mitochondria, ${ }^{33}$ these data support the concept that mitochondrial failure is a key step leading to cell death. Others, however, have reported that secondary energy failure is directly corre- 

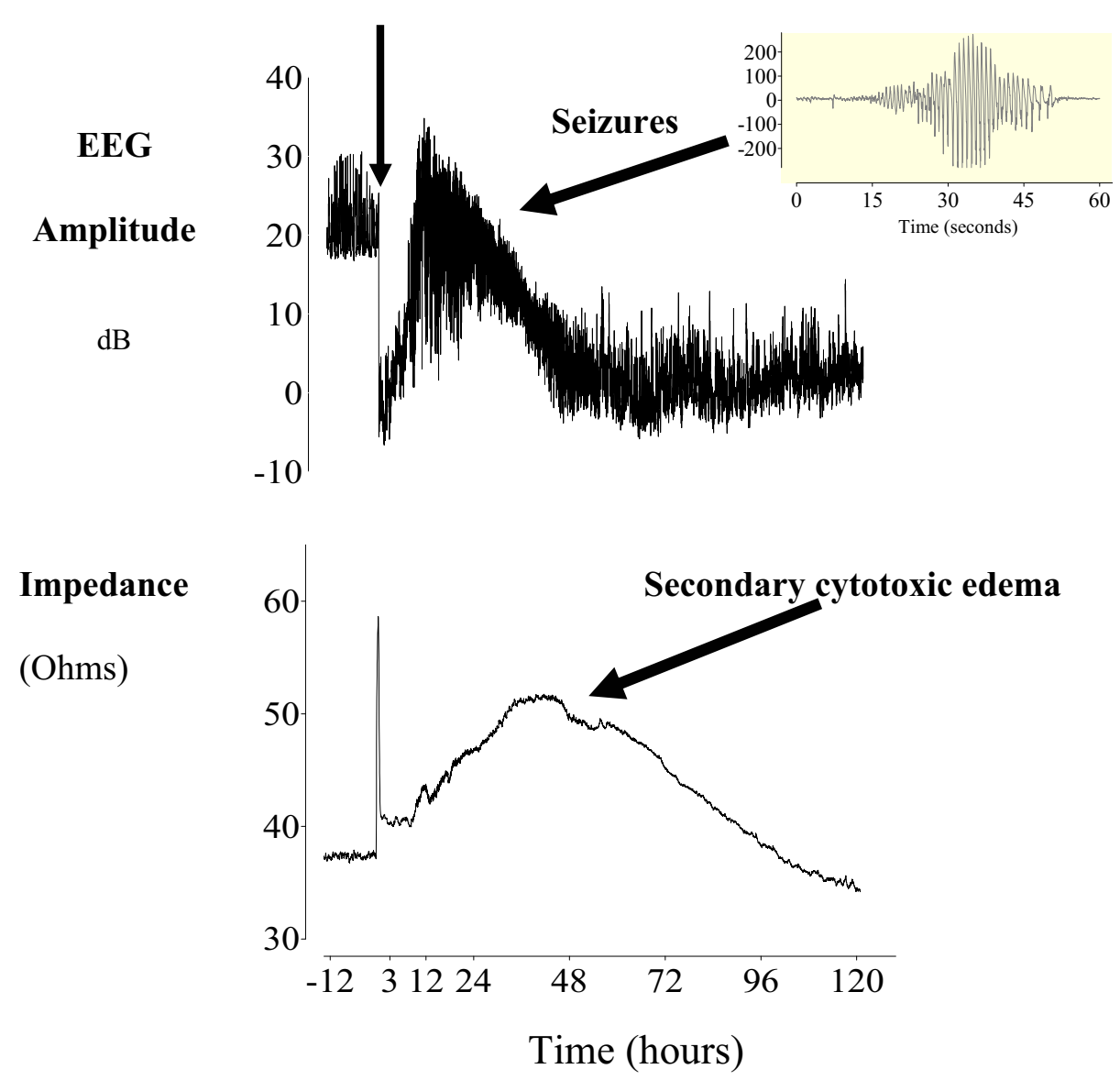

FIG. 2. Data from the near-term fetal sheep, illustrating pathophysiological events after a 30 minute episode of severe ischemia (shown by the vertical black arrow). After reperfusion, there is near-normalization of oxidative cerebral energy metabolism in the mitochondria as shown by recovery of the acute rise in impedance (a measure of cytotoxic edema) but depressed electroencephalogram (EEG) activity. From approximately $6 \mathrm{~h}$ after reperfusion there is a rapid onset of intense delayed seizures and cytotoxic edema, which begin to resolve from $36 \mathrm{~h}$. The profound suppression of the EEG after resolution of seizures correlates strongly with loss of cortical neurons. ${ }^{27}$

lated with the loss of neuronal markers at different times, ${ }^{34}$ implying that it is no more than a reflection of final cell death.

Regardless of the precise sequence of events, this consistent pattern of delayed deterioration, across species and a variety of experimental models and clinical observations suggests that the effectiveness of any treatment must be highly dependent on the timing of initiation and continuation. As discussed in detail below experimental studies of hypothermia have confirmed this hypothesis.

\section{Mechanisms of delayed cell death}

The precise events which initiate the cascade leading to delayed cell death after hypoxia-ischemia (HI) are still incompletely understood, but are undoubtedly multifactorial. It is likely partly related to excessive entry of calcium into cells both during and after hypoxia-ischemia, ${ }^{35}$ loss of trophic support from growth factors, ${ }^{36}$ induction of free radicals during hypoxia and early reperfusion, ${ }^{37,38}$ and/or a secondary inflammatory, reaction, ${ }^{39}$ which may act through activation of cell surface death receptors, ${ }^{40}$ or synthesis of down-stream mediators of cell death such as nitric oxide synthase and reactive oxygen species. ${ }^{41-43}$

Cell death may involve necrotic and apoptotic events. Necrosis is usually defined by loss of plasma membrane integrity associated with a random pattern of DNA degradation, whereas apoptosis is defined morphologically by a microscopic picture of condensation of chromatin (i.e. a dark shrunken nucleus) with 'homogenization' (loss) of the reticular formation. Ultimately the cells break down into small, neatly 'packaged' fragments. ${ }^{44}$ By analogy with the active process of developmental loss of excess cells (including neurons), it was suggested that an apoptotic morphology reflected active or "programmed' cell death. ${ }^{28,45,46}$

Post-hypoxic apoptosis can be triggered by the mechanisms discussed above, including glutamate receptor excitotoxicity and consequent intracellular calcium accumulation, ${ }^{47-49}$ inflammation, ${ }^{50}$ and oxidative stress. ${ }^{51}$ The intracytoplasmic stage of apoptosis involves alterations in the ratio of various intracellular factors such as the proto-oncogene Bcl-2, which inhibits apoptosis, and 
Bax, which promotes apoptosis,${ }^{52}$ and activation of cysteine proteases (caspases). ${ }^{53}$ The final, irreversible execution phase of apoptosis is intranuclear, involving endonuclease mediated DNA fragmentation. ${ }^{54}$ In contrast, necrosis was suggested to reflect biophysical damage to the cell (cell membrane instability, ion shifts etc), particularly lysis in the primary phase. ${ }^{28,55}$ Both patterns are clearly described in infants dying after perinatal asphyxia. $^{56,57}$

Recently, it has become clear that post-hypoxic cell death includes elements of both apoptotic and necrotic processes, with one or the other being most prominent depending on factors such as maturity and the severity of the primary insult. ${ }^{58-60}$ Consistent with this, there is evidence that mitochondrial calcium overload is a critical event in both apoptotic and necrotic cell death. ${ }^{48}$ Generally apoptosis-like or programmed cell death seems to be more important in the developing brain than in adults. ${ }^{56,57,61-66}$

Regardless of the precise pattern of delayed death, the concept remains an important one, since if neuronal and glia cell death is an active response (preprogrammed or functionally mediated by secondary mechanisms such as cytotoxin exposure), then it should logically be possible to interrupt these events.

\section{THE 'PHARMACODYNAMICS' OF HYPOTHERMIA}

\section{The timing and duration of treatment is critical}

Cooling the brain for a few hours can be modestly protective but is exquisitely dependent on the timing after the end of the hypoxia-ischemia. For example, mild hypothermia (decreasing temperature by 2 to $4^{\circ} \mathrm{C}$ ) for one to 3 hours after 15 minutes of reversible ischemia or global hypoxia in the piglet, significantly improved recovery and reduced neuronal loss 3 days later. ${ }^{67,68}$ Similar data have been reported in the neonatal rat. ${ }^{69-71}$ However, protection seems to be lost if the initiation of brief hypothermia is delayed by as little as 15 to 45 minutes after the primary insult. ${ }^{72-74}$ The observations discussed above, namely, that secondary deterioration continues for days after injury, suggest that hypothermia would be more effective if it was maintained for a relatively longer period.

Subsequent studies have strongly supported this proposal. For example, in unanesthetized infant rats subjected to moderate hypoxia-ischemia, mild hypothermia ( 2 to $3^{\circ} \mathrm{C}$ decrease in brain temperature) for 72 hours from the end of hypoxia prevented cortical infarction, while 6 hours of cooling had an intermediate effect. ${ }^{70}$ In the same model, however, a greater reduction in body temperature, of $5^{\circ} \mathrm{C}$, for 6 hours, starting immediately after the insult, gave significant neuroprotection both after 1 and 6 weeks survival as well as neurobehavioral improvement. ${ }^{75}$ Similarly, in anesthetized piglets exposed to either hypoxia with bilateral carotid ligation or to hypoxia with hypotension, either 12 hours of mild whole body hypothermia $\left(35^{\circ} \mathrm{C}\right)$ or 24 hours of head cooling with mild systemic hypothermia started immediately after hypoxia prevented delayed energy failure, ${ }^{76}$ reduced neuronal loss ${ }^{55,77}$ and suppressed post-hypoxic seizures. ${ }^{77}$

In practice, however, such early initiation of cooling is either impossible or clinically untestable, because most infants requiring resuscitation do not present with HIE at birth and many do not go on to develop HIE later. By the time that HIE can be reliably diagnosed, hours may have gone by. Thus, given that in practice treatment must start some time after birth, it was critical to determine just how late cooling could be started, and yet remain significantly protective. There is as yet no specific marker for when evolving cell death becomes irreversible. Empirically though, a range of experimental studies strongly suggest that the latent phase before secondary energy failure is established represents the realistic window of opportunity for intervention. ${ }^{78}$

For example, in the near-term fetal sheep, moderate hypothermia induced 90 minutes after reperfusion, in the early latent phase, and continued until 72 hours after ischemia, prevented secondary cytotoxic edema, and improved electroencephalographic recovery. ${ }^{27}$ There was a concomitant substantial reduction in parasagittal cortical infarction and improvement in neuronal loss scores in all regions. When the start of hypothermia was delayed until just before the onset of secondary seizures in this paradigm (5.5 hours after reperfusion) partial neuroprotection was seen (Figure 3). ${ }^{79}$ With further delay until after seizures were established (8.5 hours after reperfusion), there was no electrophysiological or overall histological protection with cooling (Figure 3). ${ }^{80}$

Similarly to the studies of early cooling, neuroprotection with delayed cooling requires relatively prolonged periods of cooling, typically longer than 12 hours. Cooling was continued for 3 days in the fetal sheep studies because pilot studies demonstrated intense rebound seizure activity and increased cell loss if cooling was stopped after less than 24 to $48 \mathrm{~h}$. In contrast, even very rapid spontaneous rewarming after 3 days of cooling was associated with only minor, transient epileptiform activity. ${ }^{81}$ These results are consistent with the report from Colbourne and colleagues in the adult gerbil that when the delay after cerebral ischemia before initiating a 24 hour period of cooling was increased from 1 to 4 hours, neuroprotection in the CA1 region of the hippocampus after six months recovery fell from 70 to $12 \% .{ }^{82}$ This chronic loss could be prevented by extending the duration of moderate ( 32 to $34^{\circ} \mathrm{C}$ ) hypothermia to 48 hours or more, even when the start of cooling was delayed until 6 hours after reperfusion. ${ }^{83,84}$ 


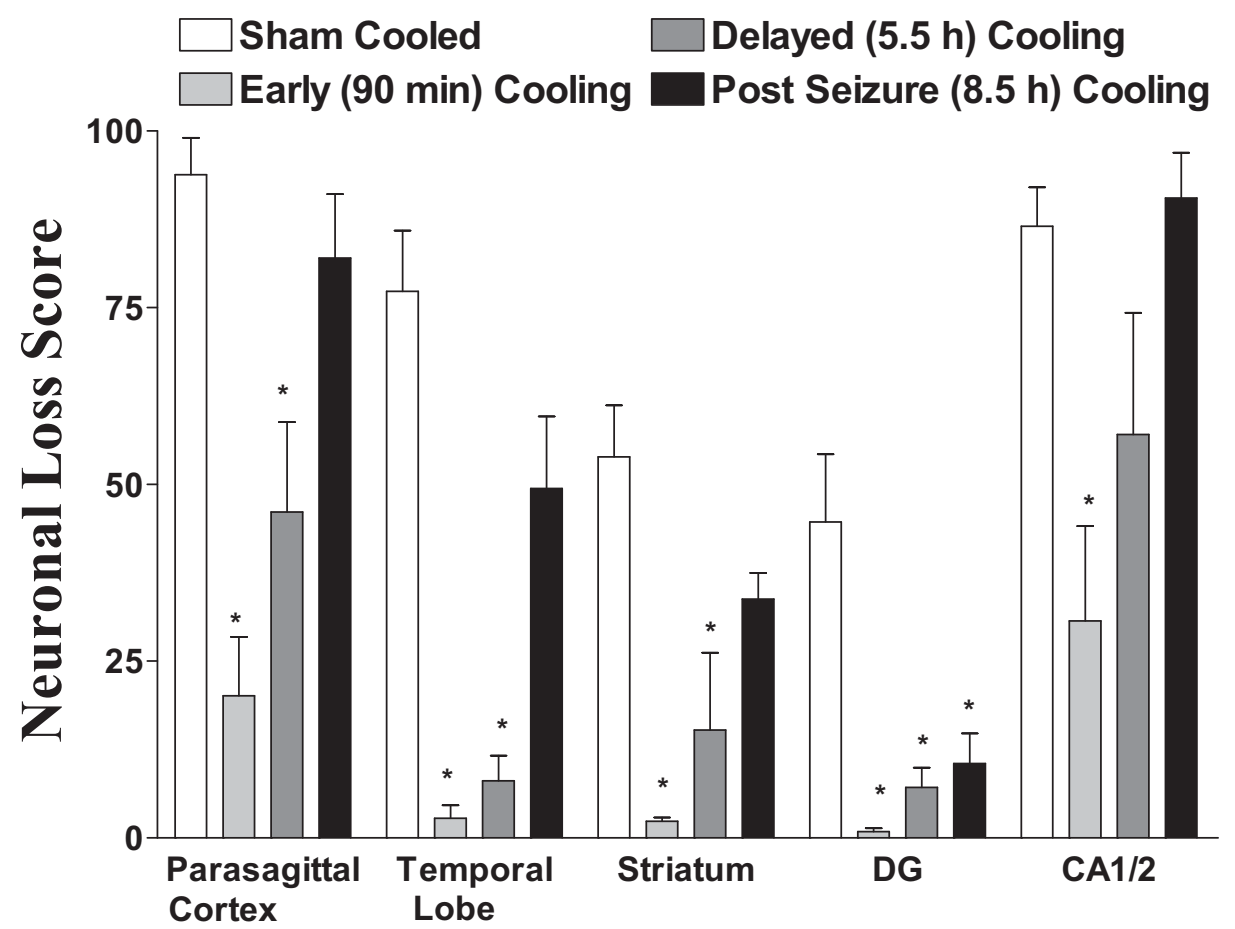

FIG. 3. The effect of cerebral cooling in the fetal sheep started at different times after reperfusion and continued until $72 \mathrm{~h}$, on neuronal loss after 5 days recovery from 30 minutes of cerebral ischemia. ${ }^{27,79,80}$ Compared with sham cooling $(n=13)$ cooling started 90 minutes after reperfusion $(n=7)$ was protective, whereas cooling started shortly after the start of the secondary phase ( 8.5 hours after reperfusion, $\mathrm{n}=5$ ) was not. Cooling started just before the end of the latent phase ( 5.5 hours after reperfusion, $n=11)$ was partially protective. Only cooled fetuses in which the extradural temperature was successfully maintained below $34^{\circ} \mathrm{C}$ have been included. DG: dentate gyrus of the hippocampus. CA1/2: cornu ammonis fields 1 and 2 of the hippocampus. ${ }^{*} p<0.005$ compared with sham-cooled (control) fetuses; data are Mean \pm SEM.

\section{How much should we cool?}

There is an obvious potential trade-off between the adverse systemic effects of cooling, which increase markedly below a core temperature of approximately $34^{\circ} \mathrm{C},{ }^{85}$ and cerebral benefits. Supporting this logic, in the adult dog, deep hypothermia (to a rectal temperature of $15^{\circ} \mathrm{C}$ ) after cardiac arrest was detrimental, whereas mild hypothermia $\left(34\right.$ to $36^{\circ} \mathrm{C}$ ), from 10 minutes until 12 hours after cardiac arrest was beneficial. ${ }^{86}$ Overall, subsequent studies suggest that a reduction in cerebral temperature to between 32 and $34^{\circ} \mathrm{C}$ is required for effective neuronal rescue. In fetal sheep cooled from 90 minutes after ischemia, substantial neuroprotection was seen only in fetuses in whom there was a sustained decrease in the extradural temperature to less than $34^{\circ} \mathrm{C}$ (normal temperature in the fetal sheep is $39.5^{\circ} \mathrm{C}$ ). ${ }^{27}$ Further, in the adult gerbil, cooling from the normal rectal temperature of $37^{\circ} \mathrm{C}$ down to $32^{\circ} \mathrm{C}$ was associated with greater behavioral and histological neuroprotection than $34^{\circ} \mathrm{C} .{ }^{87}$ Although we do not know the optimal degree of cerebral cooling in newborns, the first controlled trials of hypothermia after cardiac arrest in adults strongly support this target range, with improved neurological outcome in patients cooled to between 32 and $34^{\circ} \mathrm{C} .^{88,89}$

\section{Is neuroprotection maintained long-term?}

There have been reports that hypothermia only delayed, rather than prevented, neuronal degeneration after global ischemia in the adult rat ${ }^{90-92}$ and after relatively mild hypoxia-ischemia in the 7 day old rat. ${ }^{93}$ The most likely explanation is that the duration and / or degree of hypothermia may have been inadequate as suggested by the finding that cooling by $5^{\circ} \mathrm{C}$ for 6 hours ${ }^{75}$ or 72 hours of very mild cooling in infant rats were associated with long-term improvement after carotid occlusion and hypoxia. $^{70}$ Subsequent studies both in the 7 day rat and in adult species have confirmed that a sufficiently prolonged phase of moderate cooling can be associated with persistent behavioral and histological protection for many weeks and months. ${ }^{75,83,84,87,94-96}$ Broadly, these studies tend to suggest that the later cooling is started, the more prolonged the treatment needs to be for neuroprotection. ${ }^{97}$

\section{How does it work?}

The precise mechanisms of hypothermic neuroprotection are still unclear. Although, pragmatically, this may not matter too much to clinicians, it is critical to efforts to develop more effective combination treatments. Broadly, it is now well established that cooling sup- 

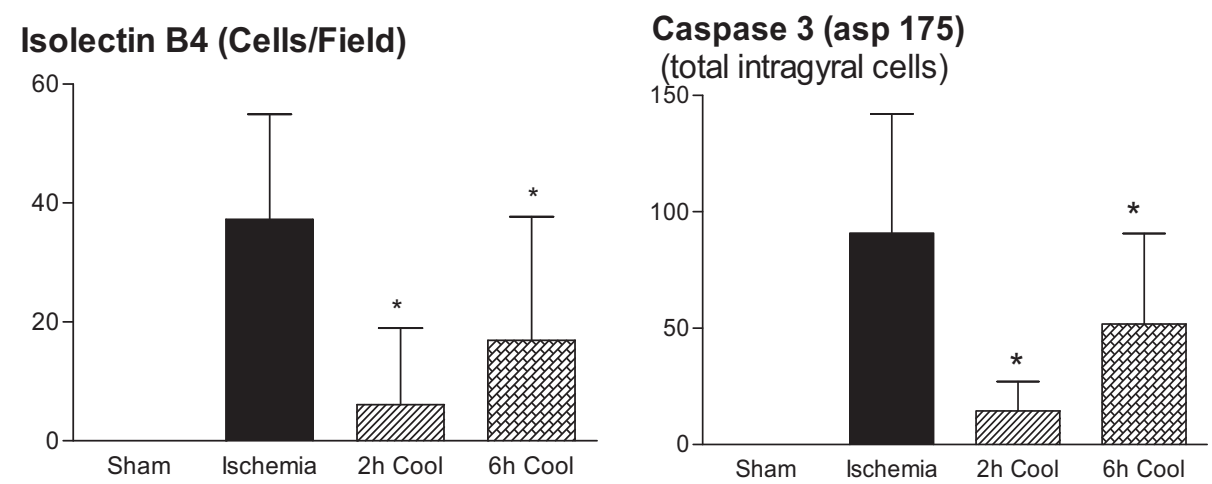

FIG. 4. Delayed head cooling is associated with suppression of both apoptotic and inflammatory processes, as shown by reduced numbers of activated microglia (isolectin B4 positive cells, left panel) and by reduced numbers of cells expressing activated caspase 3 (right panel) in subcortical white matter five days after 30 minutes of cerebral ischemia in near-term fetal sheep. ${ }^{112}$ Suppression was greater when cooling was initiated $2 \mathrm{~h}$ after the start of the ischemic insult than when it was delayed until $6 \mathrm{~h} .{ }^{112}$

presses many of the pathways leading to delayed cell death. As well as reducing cellular metabolic demands, ${ }^{98,99}$ hypothermia reduces excessive accumulation of cytotoxins such as glutamate and oxygen free radicals, suppresses the post-ischemic inflammatory reaction and inhibits the intracellular pathways leading to programmed (i.e., apoptosis-like) cell death.

Suppression of excitotoxins and free radicals. The combination of hypoxic depolarization and EAA accumulation are key factors in the initiation of neuronal injury in the primary phase, during hypoxia-ischemia. Hypothermia produces a graded reduction in cerebral metabolism of about $5 \%$ for every degree of temperature reduction, ${ }^{98}$ which delays the onset of anoxic cell depolarization. However, the protective effects of hypothermia even in this phase are not simply due to reduced metabolism, since cooling improves outcome even when the absolute duration of depolarization is controlled. ${ }^{100}$ Cooling potently reduces post-depolarization release of many toxins including EAAs in both adults, ${ }^{101}$ and newborns, ${ }^{102}$ as well as free radicals. ${ }^{103}$ Similarly, cooling started during reperfusion reduces levels of extracellular EAAs and NO production in the piglet. ${ }^{102}$

However these mechanisms rapidly resolve during the latent phase of recovery from $\mathrm{HI}$, and thus cannot readily account for the protective effects of delayed cooling.

Intracellular pathways in the latent phase. The effects of hypothermia on pathways distal to cell membrane ion channels are likely to be more important. For example, intra-insult hypothermia did not prevent intracellular accumulation of calcium during cardiac arrest in vivo, ${ }^{104}$ or during glutamate exposure in vitro. ${ }^{105}$ In contrast, in vitro neuronal degeneration was prevented by cooling initiated after the excitotoxins had been washed out. ${ }^{105}$ Thus, the ability of hypothermia to reduce release of excitotoxins does not appear to be central to its postinsult neuroprotective effects, rather these data suggest that the critical effect of hypothermia is to block the intracellular consequences of excitotoxin exposure.
Suppression of apoptosis/ programmed cell death? There is increasing evidence to suggest that hypothermia may have a particular role in suppressing the evolution of programmed cell death. Recent clinical studies have shown that apoptosis is a major contributor to postasphyxial cell death in the developing brain. ${ }^{56,57}$ Studies using morphological criteria have had mixed outcomes. In the piglet, hypothermia started after severe hypoxiaischemia was reported to reduce apoptotic cell death, but not necrotic cell death, ${ }^{55}$ with similar results reported after injury in rats. ${ }^{106,107}$ However, in the adult rat, delayed post-ischemic cell death prevented by hypothermia had a necrotic appearance on detailed electron microscopic criteria. ${ }^{108}$ However, it is now clear that apoptotic mechanisms can be involved even in 'necrotic' cell death. Although multiple pathways are likely to be involved in such post-ischemic apoptosis, caspase-3, one of the family of cysteine proteases, is reported to play a crucial role. ${ }^{109-111}$ Protection with post-ischemic hypothermia in the near-term fetal sheep was closely linked with suppression of activated caspase (Figure 4). ${ }^{112}$ These data are consistent with in vitro studies of hypothermia after severe hypoxia in developing rat neurons. Strikingly, whereas in that model preconditioning activates a program that stimulated the expression of antiapoptotic gene products and regulatory components of the cell cycle, hypothermia did not trigger active processes, but depressed cell activity and abolished hypoxiaassociated protein synthesis. ${ }^{113}$

Suppression of inflammatory second messengers. Brain injury leads to induction of the inflammatory cascade with increased release of cytokines and interleukins (IL). ${ }^{42}$ These compounds are believed to exacerbate delayed injury, whether by direct neurotoxicity and induction of apoptosis ${ }^{42}$ or by promoting stimulation of capillary endothelial cell proinflammatory responses and leukocyte adhesion and infiltration into the ischemic brain. ${ }^{43}$ There is good evidence that cooling can suppress this inflammatory reaction. In vitro, hypothermia po- 
tently inhibits proliferation, superoxide and NO production by cultured microglia. ${ }^{114}$ In the adult rat, hypothermia suppresses the post-traumatic release of IL- $1 \beta,{ }^{115}$ and the accumulation of polymorphonuclear leukocytes. ${ }^{116}$ Similarly, hypothermia delays neutrophil accumulation and microglial activation following transient ischemia (Figure 4). ${ }^{112,117}$ Thus, these data suggest that the hypothermic protection against post-ischemic neuronal damage might be, in part, due to suppression of microglial activation.

Excitotoxity after hypoxia-ischemia. Classically, cell death due to abnormal glutamate receptor activation (excitotoxicity) has been related to pathologically elevated levels of extracellular glutamate, as occurs during hypoxia-ischemia. Following reperfusion, we and others have shown that glutamate levels rapidly return to control values, ${ }^{23,25}$ and thus naively we might predict that excitotoxicity should not be important after reperfusion. However, more recent data show that pathological hyperexcitability of glutamate receptors can continue for many hours following hypoxia-ischemia, ${ }^{118-121}$ and treatment with the specific, noncompetitive NMDA antagonist MK-801 blocks this activity and improves neuronal outcome. ${ }^{122,123}$ It is still unknown whether hypothermia affects this abnormal post-hypoxic receptor function, however, brain cooling can effectively inhibit epileptiform activity, ${ }^{77,124,125}$ raising the possibility that this may well be a significant potential mechanism of action in the latent phase.

\section{Summary of clinical implications}

The experimental studies discussed above suggest that a prolonged duration of moderate cerebral hypothermia might be able to improve long-term outcome if started as soon as possible, within approximately 6 hours of hypoxic-ischemic injury. Based on these extremely encouraging data, clinical trials were undertaken.

\section{CLINICAL TRIALS OF HYPOTHERMIA}

\section{Phase I and II studies}

A number of small controlled trials of head cooling with mild hypothermia ${ }^{126-129}$ and of whole body cooling ${ }^{130}$ in asphyxiated newborns have now been reported, in addition to several case series. ${ }^{131-133}$ Although none of these studies were powered or designed to evaluate neurological outcome, there is some suggestion of improved outcomes. ${ }^{127,134,135}$ For example, in a controlled study of head cooling among infants with early stage 2 or 3 encephalopathy, mild systemic hypothermia was associated with a trend to reduced cerebral palsy in survivors (odds ratio $0.46[0.08,2.56]$ vs normothermia). ${ }^{127} \mathrm{~A}$ retrospective study of whole body cooling to between 32 and $34^{\circ} \mathrm{C}$ in 10 infants found a significant reduction of major neurologic abnormalities and abnormal MRI find- ings at follow-up compared with 11 historical controls. ${ }^{134}$ A larger randomized pilot study of head cooling with mild hypothermia compared to normothermia found a significant reduction in neuron specific enolase (NSE) levels in cerebral spinal fluid with cooling but only a small increase in normal developmental outcome at 6 months of age in 18 of 23 cooled patients $(78.3 \%)$ compared with 19 of $27(70.4 \%)$ normothermic infants. ${ }^{135}$

Finally, a large phase II randomized clinical trial of 65 infants has been reported, in which body cooling to a rectal temperature of $33{ }^{\circ} \mathrm{C}$ for 48 hours was initiated within 6 hours of birth. In contrast with the previous studies, the deeper central cooling in this study was associated with some adverse effects although these were clinically manageable, including longer dependence on inotropic agents, prolongation of prothrombin times, and lower platelet counts with more patients requiring plasma and platelet transfusions. ${ }^{136}$ The combined outcome of death or severe motor scores was significantly lower in the hypothermia group (52\%) than the normothermia group $(84 \%)(\mathrm{P}=0.019) .{ }^{137}$ Severely abnormal motor scores were recorded in $64 \%$ of normothermia patients and in $24 \%$ of hypothermia patients.

\section{Phase III studies}

The first large multicenter randomized controlled trial of hypothermia for HIE was the CoolCap trial. ${ }^{138,139}$ In this study of term infants with moderate to severe HIE, head cooling with mild systemic hypothermia, defined as a rectal temperature of $34-35{ }^{\circ} \mathrm{C}(\mathrm{n}=116)$, or conventional care $(n=118)$, death or disability at 18 months was reduced in infants with less severe electroencephalographic changes at trial entry $(n=172$, odds ratio 0.42 ; 95\% CI $0.22-0.80, \mathrm{p}=0.009) .{ }^{138}$ In contrast, however, there was no benefit in those with the combination of seizures and profound suppression of the amplitude integrated electroencephalogram (aEEG) recording before cooling was started. The improvement was primarily due to a reduction in motor disability, with a more than 50 percent reduction in severe neuromotor disability in survivors and improved continuous BSID-II scores. In contrast there was no change in early neonatal mortality ( 27 cooled vs. 26 control cases), with a small apparent reduction in late mortality ( 9 vs. 16 cases respectively). Although this is not a large category, the difference in late events is intriguing since the great majority of late deaths in both groups were related to complications of severe disability.

These data suggest that cooling can safely improve survival without severe neurodevelopmental disability in infants with less severe aEEG changes. The only consistent minor adverse effects were scalp edema under the cap, which resolved rapidly before or after removal of the cap, transient hyperglycemia from 4 to 24 hours 
compared with controls (mean $\pm \mathrm{SD}, 7.6 \pm 4.4$ vs. $5.4 \pm 3.1 \mathrm{mmol} / \mathrm{L}$, at 4 hours, $\mathrm{p}<0.001$ ), and sinus bradycardia (which is a well known, essentially normal response during hypothermia ${ }^{140}$ ) that did not require treatment. Conversely, there was an apparent reduction in the incidence of elevated liver enzymes in the cooled group $(38 \%$ of cooled infants vs $53 \%$ of controls, $\mathrm{p}=0.02)$.

In a second large multi-center trial, this time of whole body cooling, Shankaran and colleagues enrolled 208 infants who met specific clinical and laboratory criteria suggesting exposure to severe perinatal hypoxia and had moderate or severe HIE on neurological examination by trained examiners. ${ }^{141}$ Infants in the experimental group $(n=102)$ were placed on a cooling blanket and cooled to a rectal temperature of $33.5 \pm 0.5^{\circ} \mathrm{C}$ for 72 hours. After 18 months of follow up, the incidence of death and/or moderate-to-severe disability was significantly reduced in the cooled infants $(45 \%)$ vs the normothermic group (62\%, relative risk $0.72 ; 95 \% \mathrm{CI}, 0.55-0.93)$. There was no difference for death or disability alone.

\section{Other ongoing trials}

A number of trials are still in progress, including the Total Body Cooling trial (TOBY) in England, the NeoNetwork trial in central Europe and the Infant Cooling Evaluation (ICE) trial in Western Australia. The TOBY trial's inclusion criteria are identical to those of the CoolCap trial. This trial should allow direct comparison of total body vs head cooling in patients meeting the same inclusion criteria. The NeoNetwork trial is a whole body cooling trial using a target rectal temperature of $33.5^{\circ}$ for $72 \mathrm{~h}$, with similar entry criteria to the TOBY trial using a cooling blanket. The ICE trial aims to enroll infants from a wide geographic region, using a simplified, pragmatic protocol. A target rectal temperature of $33^{\circ}-34^{\circ} \mathrm{C}$ is achieved by turning off the ambient heating systems and by applying "Hot-Cold" gel packs (cooled to $10^{\circ} \mathrm{C}$ ) around the infant's head and chest. In a preliminary report on 26 infants with HIE who were randomized to normothermia or to systemic hypothermia, Inder and colleagues reported that the hypothermia group had less cortical gray matter signal abnormality on magnetic resonance imaging (MRI) (1/12 vs $7 / 14$ infants in the normothermic group; $\mathrm{P}=.036$ ), but had similar numbers of basal ganglia lesions, which raises the possibility of selective regional benefits from treatment with hypothermia. ${ }^{142}$ Interestingly, Rutherford and colleagues have also reported a reduced incidence of severe cortical lesions in infants treated with head cooling. ${ }^{143}$ However, in that report, both head and whole body cooling were associated with a decrease in basal ganglia and thalamic lesions that was significant in infants with moderate aEEG changes but not in those with severe aEEG findings. ${ }^{143}$

\section{UNANSWERED QUESTIONS}

Taken together, the remarkably similar effect sizes in two independent, well controlled studies strongly suggest that induced hypothermia is beneficial. In many ways, as often happens, these studies have actually raised many more questions than they answered. In particular, the multicenter trials reported to date make it clear that neuroprotection with hypothermia as currently used is only partial, such that many patients die of neural injury or survive with disability despite hypothermia. ${ }^{138,141}$ This issue is not limited to neonatal HIE, since trials of cooling for neurological recovery after adult comatose cardiac arrest have suggested a similar limitation. ${ }^{88,89}$ Both the two neonatal and the adult cardiac arrest trials have suggested that the number needed to treat is approximately 6 , meaning that 6 patients need to receive the intervention for one to have a positive outcome. In this section, we will focus on issues relating to the practical use (and abuse) of therapeutic hypothermia.

\section{How late is really too late?}

The real clinical window of opportunity for treatment, with hypothermia, or any other putative therapy, is simply not clear. It may well be both longer and shorter than suggested by experimental work. It is important to appreciate some of the limitations of the experimental studies. Crucially they used very carefully standardized insults, occurring at a precisely known time. In contrast, the precipitating insult in neonatal encephalopathy is a well defined event, such as placental abruption that is terminated at birth, in only approximately $25 \%$ of cases. ${ }^{144}$ In other cases the preceding insult seems to evolve over hours during labor, and in at least some cases, perhaps $10 \%$ of the total, the infant seems to have been compromised even before labor started. ${ }^{144,145}$ Thus, it seems very likely that the effective window of opportunity to treat HIE will, in some cases, be somewhat less than suggested experimentally. The clinical trials were unable to address this issue, as too few infants were able to start treatment early after birth; just $12 \%$ of infants started treatment before $4 \mathrm{~h}$ in the CoolCap trial for example. $^{138}$

Equally, we must also recognize that the speed of evolution of delayed cell death is a function of severity of injury. Milder insults are associated with much more delayed neuronal loss. ${ }^{28,146}$ Thus, whereas the most severe insults may need treatment essentially at the time of resuscitation, or be untreatable, it remains possible that more mildly affected infants, such infants who have long-term learning difficulties but no handicap, could benefit from cooling even after $6 \mathrm{~h}$. This does not imply of course that such delay is anyway desirable or acceptable, merely that if unavoidable, it might, in a narrowly defined subset of children, still have some benefit. 


\section{Who should be treated, or: How bad is too bad?}

Following on from this issue, it is possible that one reason for the limited response in the two multicenter trials may have been that the trials recruited many infants who were 'untreatable'. The foundation studies of secondary energy failure in children with HIE showed that some infants with apparent hypoxic-ischemic encephalopathy did not show any initial recovery of cerebral oxidative metabolism, and have extremely poor outcomes, typically death. ${ }^{18}$ This finding should not be over-interpreted; the number of MRS studies that could be performed was limited, and so brief recovery of energy metabolism could have been missed. Further, although such cases may never be treatable, many infants with moderate to severe hypoxic-ischemic encephalopathy do show initial, transient recovery of cerebral oxidative metabolism. ${ }^{18,19}$

Nonetheless, ideally, we would like to identify the potentially treatable cases in advance, to avoid offering false hope, and to target treatment more effectively. Clinical evaluation of the severity of HIE, using criteria modified from Sarnat and Sarnat, was highly predictive of the risk of death or disability in both trials. Despite this, strikingly, and contrary to the authors' and many others' original expectations at the time that the trials were developed, the relative improvement was similar both for infants with moderate (Stage II) and severe (Stage III) HIE. ${ }^{139,141}$ Thus despite its prognostic reliability, clinical evaluation does not seem to distinguish between 'treatable' and 'untreatable' cases.

In contrast, the CoolCap trial suggested that EEG monitoring could identify a subgroup of infants with profound suppression of amplitude and onset of seizures at the time of randomization who did not respond. ${ }^{138} \mathrm{Al}-$ though these findings are extremely suggestive, it is important to take in to account several potential limitations of these findings. The EEG recruitment criteria were designed primarily to exclude cases of mild HIE (who have a known normal outcome) rather than to distinguish 'treatable' from 'untreatable' infants, and the EEG interpretation of a 20 min compressed trace was performed by site investigators, of whom few had previous experience in assessing aEEG, not experts. Pragmatically, and perhaps most importantly, this is the first and to date only study to examine this question.

Thus, the authors believe that it is premature to judge this issue. The Sarnat and Sarnat score for example was developed many decades ago, ${ }^{147}$ and is based on assessment of infants who are more than 24 hours old, before the therapeutic era. Focused clinical and animal studies are now needed to investigate whether there may be components of clinical examination, biochemical tests or of EEG recordings that might be more predictive of the timing (as opposed to severity) of HIE and of the response to cooling.

\section{Is head or whole body cooling better?}

In order to provide adequate neuroprotection with minimal risk of systemic adverse effects in sick, unstable neonates, ideally only the brain would be cooled. Although this has been demonstrated experimentally using cardiac bypass procedures, ${ }^{148}$ it is clearly impractical in routine practice. Pragmatically, partially selective cerebral cooling can be obtained using a cooling cap applied to the scalp, while the body is warmed by some method such as an overhead heater to limit the degree of systemic hypothermia. ${ }^{126,128,149} \mathrm{~A}$ mild $\left(\sim 34\right.$ to $\left.35^{\circ} \mathrm{C}\right)$ degree of systemic hypothermia is still desirable during head cooling; firstly to reduce the steepness of the intracerebral gradient which develops during true selective head cooling, ${ }^{150}$ avoiding excessively cold cap temperatures which might cause scalp injury or exacerbate local scalp edema, ${ }^{128}$ and to provide at least some cooling of deep cerebral structures such as the brain stem. This approach has recently been demonstrated in the piglet to be associated with a substantial (median, $5.3^{\circ} \mathrm{C}$ ), sustained decrease in deep intracerebral temperature at the level of the basal ganglia compared with the rectal temperature. ${ }^{151,152}$ Figure 5 shows examples of changes in regional brain temperatures in piglets, either during moderate whole body cooling, to a rectal temperature of $34.5^{\circ} \mathrm{C}$, or head cooling combined with moderate central hypothermia to $34.5^{\circ} \mathrm{C}$. During whole body cooling there was less than $0.6^{\circ} \mathrm{C}$ difference between the warmest (basal ganglia) and the coldest parts of the brain (the cortex). In contrast, during head cooling there was an approximately $6^{\circ} \mathrm{C}$ gradient between the superficial and deep brain. Nevertheless, in the $1.5 \mathrm{~kg}$ term piglet, which has a smaller head relative to body size than the human, it was possible to use this cooling cap to maintain the deep part of the brain a mean of $3.4{ }^{\circ} \mathrm{C}$ colder than rectal temperature for more than $24 \mathrm{~h}^{152} \mathrm{~A}$ gradient of over $6{ }^{\circ} \mathrm{C}$ was achieved in a subsequent study, ${ }^{153}$ suggesting that the small premature head could be selectively cooled.

Overall, these data suggest that partially selective cooling of the head is likely to be feasible. Consistent with this, in asphyxiated newborns, although direct temperature measurements are not yet generally feasible, head cooling has been shown to increase the gradient between nasopharyngeal and rectal temperature by approximately $1{ }^{\circ} \mathrm{C} .{ }^{126}$ However, it is not possible to tell from the recent trials whether it is more or less effective than whole body cooling. Intriguingly, recent short-term recovery studies in the piglet do suggest that the optimal degree of cooling is greater in the cortex than in the basal ganglia. ${ }^{154}$ Supporting this experimental observation, in a recent case series, head cooling but not whole body cooling seemed to be associated with a reduction in the incidence of severe cortical lesions, ${ }^{143}$ as examined by MRI. If this is correct, we would predict that the long-term followup 

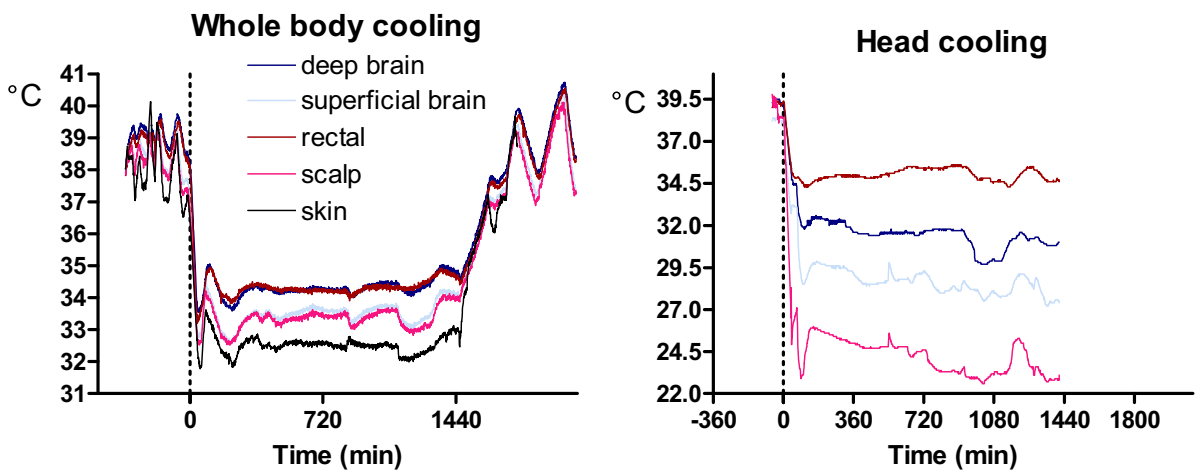

FIG. 5. Examples of cooling in term piglets showing that during whole body cooling the deep brain temperature closely approximates rectal temperature (Left). In contrast, during head cooling it is possible to maintain deep brain structures at significantly lower temperature than the rectal temperature. This method of cooling may further limit the side effects associated with systemic hypothermia and be feasible for premature infants. ${ }^{153}$

of the CoolCap study may show a greater effect on cognitive ability.

\section{How long should cooling be continued?}

Based on the experimental data discussed earlier, all of the recent clinical studies have continued cooling for 48 to $72 \mathrm{~h}$. There is robust evidence from adult rodent models that cooling for $48 \mathrm{~h}$ is better than for $24 \mathrm{~h}^{83,84}$; indeed the authors have observed rebound deterioration after $24 \mathrm{~h}$ in the fetal sheep (unpublished). However, it is unclear whether cooling for $72 \mathrm{~h}$ is 'better' than $48 \mathrm{~h}$. Equally, there are experimental and clinical data reporting rebound seizure activity after rewarming from $72 \mathrm{~h}$ of cooling, ${ }^{81,155}$ and thus it remains possible that cooling for 4 or 5 days might provide further benefit.

Alternatively there is some evidence that rapid rewarming can impair recovery, with transient uncoupling of cerebral circulation and metabolism, ${ }^{156}$ and in adult rats can exacerbate traumatic axonal injury and impair cerebrovascular responsiveness, compared with slow rewarming. ${ }^{157,158}$ There are no systematic data from large animals. The clinical studies of therapeutic hypothermia have empirically chosen to rewarm infants at no more than $0.5^{\circ} \mathrm{C}$ per $\mathrm{h},{ }^{128,130,132}$ however, it remains possible that rewarming still more slowly might be beneficial. Further, there is some evidence that worsening of intracranial pressure during rewarming in adult patients with head injury may be able to be avoided by an extremely slow rewarming schedule, although it is still not known whether this improves long-term outcomes. This is an area where significant further experimental work in large species would be helpful.

\section{How much should we cool?}

This is one area where the clinical studies did not closely follow the experimental evidence. As previously reviewed, in general the evidence is that five degrees of cooling (approximately a rectal temperature of $32{ }^{\circ} \mathrm{C}$ ) is better than a reduction of three degrees (equivalent to 34 $\left.{ }^{\circ} \mathrm{C}\right) .{ }^{159}$ The trials of whole body cooling however have used a target rectal temperature of around $33.5^{\circ} \mathrm{C}$. This suggests that at present we are using the upper half of the ideal range, and that deeper cooling, at least for a time, might allow still greater cerebral protection. The reason for this discrepancy is of course that the clinicians designing the studies were most concerned not to cause side effects in these highly unstable infants. As reviewed next, mild cooling in an intensive care environment has been impressively safe. Only large clinical trials can inform us whether this would also be true of deeper cooling.

\section{Just how safe is cooling in infants with HIE?}

While the above studies have suggested that mild hypothermia is generally safe they have also highlighted the importance of understanding the physiological impact of hypothermia. ${ }^{85}$ It is important to appreciate that although for example, there was no increase in the rate of complications such as infection in the newborn studies, this likely reflects in large part the design of these trials, which included both routine screening and treatment for possible infection. ${ }^{138,141}$ Hypothermia has profound antiinflammatory effects and in older adults seems to increase the risk of infective complications such as pneumonia and bacteremia, ${ }^{85,160}$ and thus this potential risk needs to continue to be carefully monitored in clinical use. Similarly, as noted above, although no increase in hemorrhagic complications was reported in either of the two phase III trials, ${ }^{138,141}$ Eicher et al have reported such an increase in association with still lower body temperatures. ${ }^{136}$ It is unclear at this time whether this is a specific concern with cooling to $33^{\circ} \mathrm{C}$ and lower, or simply a chance finding. It is reassuring that in piglet studies where the cortex was cooled significantly (less than 30 degrees) no hemorrhagic changes were seen in the brain. 77,153

One consistent metabolic effect associated with hypothermia was transient mild hyperglycemia, both in adult ${ }^{88}$ and infant trials, ${ }^{138}$ with no increase in the rate of 
hypoglycemia. A similar transient initial rise in glucose concentrations has been observed in the piglet and nearterm fetal sheep, ${ }^{27,161}$ In the piglet, as cooling was continued increased glucose administration became necessary to maintain normal levels. ${ }^{161}$ It is probable that the initial rise in glucose levels reflects hypothermia-induced catecholamine release.

Cardiovascular effects include a significant increase in blood pressure at initiation of cooling, both experimentally ${ }^{79}$ and clinically. ${ }^{131}$ This response is mediated by rapid peripheral vasoconstriction, i.e. centralization of blood flow. ${ }^{162}$ Further, hypothermia slows the atrial pacemaker and intracardiac conduction. Consequently, hypothermia to less than approximately $35.5^{\circ} \mathrm{C}$ is associated with mild but sustained sinus bradycardia, however this has not required treatment. ${ }^{128,130,138,141}$ This linear relation between heart rate and core temperature likely partly reflects the increased metabolic need with increasing temperature. Electrocardiograms done in infants with sustained heart rates of $<90 \mathrm{bpm}$ confirmed that some show markedly prolonged QT duration above the $98^{\text {th }}$ percentile corrected for age and heart rate, without arrhythmia. These changes resolve with rewarming. ${ }^{163}$ Although such prolonged QT in the absence of ventricular arrhythmia may be safe, close monitoring is clearly essential and other therapies which lengthen the QT interval (such as macrolide antibiotics) should be avoided.

\section{With what should cooling be given?}

One potential way of improving the effectiveness of treatment would be to combine cooling with another agent. There is increasing evidence that hypothermia can markedly augment the effects of drug therapy. For example, post-ischemic hypothermia attenuated neurobehavioral deficits in adult rats when combined with delayed NMDA receptor antagonist treatment, more than either treatment alone, ${ }^{164}$ and synergistically enhanced the protective effects of MK-801 during hypoxia-ischemia in the neonatal rat. ${ }^{165,166}$ Similarly, in the neonatal rodent, a combination of xenon and hypothermia administered 4 hours after hypoxic-ischemic injury provided synergistic neuroprotection up to 30 days after the insult. ${ }^{167}$ Xenon is known to be an antagonist of the Nmethyl-D-aspartate subtype of the glutamate receptor, and thus, this finding also supports this general approach. Further, it is of interest that in the piglet model of global hypoxia-ischemia neuroprotection and improved neurological function were seen only when the subjects were anaesthetized during the hypothermic period, suggesting a potentially important interaction between hypothermia and sedation / anesthesia. ${ }^{168}$

A simple increase in protection is not the only useful outcome from combination treatment. For example, in the rat, repeated intraperitoneal doses of a glutamate antagonist substantially delayed the eventual development of neuronal loss in the hippocampus. ${ }^{169}$ It is unknown whether more prolonged treatment might have had permanent protection, however, it suggests that this or similar agents might be used to prolong the window of opportunity for other therapies. Consistent with this postulate, Liu and colleagues have recently reported that injection of a single dose of an AMPA/KA receptor antagonist, Topiramate, after hypoxia-ischemia in the neonatal rat was not protective by itself, but that this treatment significantly extended the window of opportunity for protection with a short $(3 \mathrm{~h})$ interval of hypothermia. ${ }^{170}$ Conversely, in the adult rat, brief, mild hypothermia which was not significantly protective in its own right, markedly increased the window of opportunity for treatment with the anti-apoptotic agent insulinlike growth factor 1 after hypoxia-ischemia. ${ }^{171}$

MK-801 has been one of the most extensively investigated glutamate antagonists. However, this drug and others, have numerous, clinically unacceptable side effects. Treatment can cause hallucinations, sedation and learning and memory deficits since it indiscriminately blocks physiologic effects at the NMDA receptor at neuroprotective doses. ${ }^{172}$ NMDA receptor blockade impairs induction of long-term potentiation (LTP) which is important for memory formation. ${ }^{173}$ In addition, MK-801 causes acute but reversible neuronal vacuolization when systemically administered at neuroprotective doses in adult rodents. ${ }^{174}$ Even more concerning, in the developing brain NMDA antagonists such as MK-801 have long lasting effects on neuronal circuits, ${ }^{175}$ can trigger widespread apoptotic neurodegeneration in the developing brain ${ }^{176}$ and indeed while MK-801 after head injury protected against primary necrotic damage it actually increased severity of secondary apoptotic damage. ${ }^{177}$

Thus, at present, despite the considerable promise of this approach, much more basic investigation is required to identify the most effective and clinically acceptable agent for use in combination therapy with hypothermia.

\section{CONCLUSION}

There is now nearly overwhelming clinical and experimental evidence that moderate cerebral cooling after cardiac arrest and in infants with acute hypoxic-ischemic encephalopathy can improve medium-term neurological recovery in at least some infants. The long-term effects of hypothermia, at school age and later, are not yet known, but we can be cautiously optimistic, while awaiting the results of the studies which are still in progress. The key therapeutic requirements for neuroprotection are that hypothermia is initiated as soon as possible in the latent phase, prior to secondary deterioration, and continued for a sufficient period in relation to the evolution 
of delayed encephalopathic processes, typically 48 hours or more.

The studies to date show that although hypothermia is an important advance, as currently applied it is not a 'magic bullet'. Only approximately $15 \%$ have better outcome after cooling group as compared to those treated with standard care. Many important clinical questions, which we may summarize as: when, how deep, how long, to whom, by what method and combined with what, will need to be answered before we can really know how best to use hypothermia.

Acknowledgments: The authors' work reported in this review has been supported by grants from the Health Research Council of New Zealand, Lottery Health Board of New Zealand, the Auckland Medical Research Foundation, The Norwegian Research Council, Laerdal Foundation for Acute Medicine, The Wellcome Trust and SPARKS (UK).

\section{REFERENCES}

1. Gunn AJ, Gunn TR. Changes in risk factors for hypoxic-ischaemic seizures in term infants. Aust N Z J Obstet Gynaecol 37:36-39, 1997.

2. Floyer J. An essay to restore the dipping of infants in their baptism; with a dialogue betwixt a curate and a practitioner, concerning the manner of immersion. London: Holland, 1722.

3. Polderman KH. Application of therapeutic hypothermia in the ICU: opportunities and pitfalls of a promising treatment modality. Part 1: Indications and evidence. Intensive Care Med 30:556-75, 2004.

4. Hippocrates. De Vetere Medicina. Translation: Jones WHS, Withington ET. Loeb Classical Library, 460-375 BC.

5. Larrey IJ. In: Memoirs of military service and campaigns of the French armies. [Vol. 2], pp 156-164. Baltimore: Cushing, 1814.

6. Fay T. Early experiences with local and generalized refrigeration of the human brain. J Neurosurg 16:239-259, 1959.

7. Rosomoff HL. Hypothermia and cerebral vascular lesions. I. Experimental interruption of the middle cerebral artery during hypothermia. J Neurosurg 13:244-55, 1956.

8. Rosomoff HL, Holaday DA. Cerebral blood flow and cerebral oxygen consumption during hypothermia. Am J Physiol 179: 85-8, 1954.

9. Westin B, Miller JA, Jr., Boles A. Hypothermia induced during asphyxiation: its effects on survival rate, learning and maintenance of the conditioned response in rats. Acta Paediatr 52:4960, 1963.

10. Nurse S, Corbett D. Direct measurement of brain temperature during and after intraischemic hypothermia: correlation with behavioral, physiological, and histological endpoints. J Neurosci 14:7726-7734, 1994.

11. Westin B, Miller JA, Jr., Nyberg R, Wedenberg E. Neonatal asphyxia pallida treated with hypothermia alone or with hypothermia and transfusion of oxygenated blood. Surgery 45:86879, 1959.

12. Miller JA, Jr., Miller FS, Westin B. Hypothermia in the Treatment of Asphyxia Neonatorum. Biol Neonat 20:148-63, 1964.

13. Cordey R. Hypothermia in Resuscitating Newborns in White Asphyxia; a Report of 14 Cases. Obstet Gynecol 24:760-7, 1964.

14. Cordey R, Chiolero R, Miller JA, Jr. Resuscitation of neonates by hypothermia: report on 20 cases with acid-base determination on 10 cases and the long-term development of 33 cases. Resuscitation 2:169-81, 1973.

15. Dunn JM, Miller JA, Jr. Hypothermia combined with positive pressure ventilation in resuscitation of the asphyxiated neonate. Clinical observations in 28 infants. Am J Obstet Gynecol 104: $58-67,1969$.
16. Silverman WA, Fertig JW, Berger AP. The influence of the thermal environment upon the survival of newly born premature infants. Pediatrics 22:876-86, 1958.

17. Bohn DJ, Biggar WD, Smith CR, Conn AW, Barker GA. Influence of hypothermia, barbiturate therapy, and intracranial pressure monitoring on morbidity and mortality after near-drowning. Crit Care Med 14:529-34, 1986.

18. Azzopardi D, Wyatt JS, Cady EB, Delpy DT, Baudin J, Stewart AL, et al. Prognosis of newborn infants with hypoxic-ischemic brain injury assessed by phosphorus magnetic resonance spectroscopy. Pediatr Res 25:445-51, 1989.

19. Roth SC, Edwards AD, Cady EB, Delpy DT, Wyatt JS, Azzopardi D, et al. Relation between cerebral oxidative metabolism following birth asphyxia, and neurodevelopmental outcome and brain growth at one year. Dev Med Child Neurol 34:285-295, 1992.

20. Roth SC, Baudin J, Cady E, Johal K, Townsend JP, Wyatt JS, et al. Relation of deranged neonatal cerebral oxidative metabolism with neurodevelopmental outcome and head circumference at 4 years. Dev Med Child Neurol 39:718-25, 1997.

21. Lorek A, Takei Y, Cady EB, Wyatt JS, Penrice J, Edwards AD, et al. Delayed ("secondary") cerebral energy failure after acute hypoxia-ischemia in the newborn piglet: continuous 48-hour studies by phosphorus magnetic resonance spectroscopy. Pediatr Res 36:699-706, 1994.

22. Mehmet H, Yue X, Penrice J, Cady E, Wyatt JC, Sarraf C, et al. Relation of impaired energy metabolism to apoptosis and necrosis following transient cerebral hypoxia-ischaemia. Cell Death Differ 5:321-329, 1998.

23. Tan WK, Williams CE, During MJ, Mallard CE, Gunning MI, Gunn AJ, et al. Accumulation of cytotoxins during the development of seizures and edema after hypoxic-ischemic injury in late gestation fetal sheep. Pediatr Res 39:791-797, 1996.

24. Williams CE, Gunn A, Gluckman PD. Time course of intracellular edema and epileptiform activity following prenatal cerebral ischemia in sheep. Stroke 22:516-521, 1991.

25. Obrenovitch TP, Richards DA. Extracellular neurotransmitter changes in cerebral ischaemia. Cerebrovasc Brain Metab Rev 7:1-54, 1995.

26. Gunn AJ, Parer JT, Mallard EC, Williams CE, Gluckman PD. Cerebral histologic and electrocorticographic changes after asphyxia in fetal sheep. Pediatr Res 31:486-491, 1992.

27. Gunn AJ, Gunn TR, de Haan HH, Williams CE, Gluckman PD. Dramatic neuronal rescue with prolonged selective head cooling after ischemia in fetal lambs. J Clin Invest 99:248-256, 1997.

28. Beilharz EJ, Williams CE, Dragunow M, Sirimanne ES, Gluckman PD. Mechanisms of delayed cell death following hypoxicischemic injury in the immature rat: evidence for apoptosis during selective neuronal loss. Mol Brain Res 29:1-14, 1995.

29. Dimlich RV, Showers MJ, Shipley MT. Densitometric analysis of cytochrome oxidase in ischemic rat brain. Brain Res 516:181-91, 1990.

30. Wagner KR, Kleinholz M, Myers RE. Delayed decreases in specific brain mitochondrial electron transfer complex activities and cytochrome concentrations following anoxia/ischemia. J Neurol Sci 100:142-51, 1990.

31. Nelson C, Silverstein FS. Acute disruption of cytochrome oxidase activity in brain in a perinatal rat stroke model. Pediatr Res 36:12-9, 1994.

32. Wagner KR, Kleinholz M, Myers RE. Delayed onset of neurologic deterioration following anoxia/ischemia coincides with appearance of impaired brain mitochondrial respiration and decreased cytochrome oxidase activity. J Cereb Blood Flow Metab 10:417-23, 1990.

33. Schild L, Huppelsberg J, Kahlert S, Keilhoff G, Reiser G. Brain mitochondria are primed by moderate $\mathrm{Ca} 2+$ rise upon hypoxia/ reoxygenation for functional breakdown and morphological disintegration. J Biol Chem 278:25454-60, 2003.

34. Vannucci RC, Towfighi J, Vannucci SJ. Secondary energy failure after cerebral hypoxia-ischemia in the immature rat. J Cereb Blood Flow Metab 24:1090-7, 2004. 
35. Zipfel GJ, Babcock DJ, Lee JM, Choi DW. Neuronal apoptosis after CNS injury: the roles of glutamate and calcium. J Neurotrauma 17:857-69, 2000

36. Clawson TF, Vannucci SJ, Wang GM, Seaman LB, Yang XL, Lee WH. Hypoxia-ischemia-induced apoptotic cell death correlates with IGF-I mRNA decrease in neonatal rat brain. Biol Signals Recept 8:281-93, 1999.

37. Bagenholm R, Nilsson UA, Gotborg CW, Kjellmer I. Free radicals are formed in the brain of fetal sheep during reperfusion after cerebral ischemia. Pediatr Res 43:271-275, 1998.

38. Yan EB, Unthank JK, Castillo-Melendez M, Miller SL, Langford SJ, Walker DW. Novel method for in vivo hydroxyl radical measurement by microdialysis in fetal sheep brain in utero. $J \mathrm{Appl}$ Physiol 98:2304-10, 2005.

39. Giulian D, Vaca K. Inflammatory glia mediate delayed neuronal damage after ischemia in the central nervous system. Stroke 24: I84-90, 1993.

40. Graham EM, Sheldon RA, Flock DL, Ferriero DM, Martin LJ, O'Riordan DP, et al. Neonatal mice lacking functional Fas death receptors are resistant to hypoxic-ischemic brain injury. Neurobiol Dis 17:89-98, 2004.

41. Gehrmann J, Banati RB, Wiessner C, Hossmann KA, Kreutzberg GW. Reactive microglia in cerebral ischaemia: an early mediator of tissue damage? Neuropathol Appl Neurobiol 21:277-89, 1995.

42. Allan SM, Rothwell NJ. Inflammation in central nervous system injury. Philos Trans R Soc Lond B Biol Sci 358:1669-77, 2003.

43. Silverstein FS, Barks JD, Hagan P, Liu XH, Ivacko J, Szaflarski J. Cytokines and perinatal brain injury. Neurochem Int 30:37583, 1997.

44. Jacobson MD, Weil M, Raff MC. Programmed cell death in animal development. Cell 88:347-54, 1997.

45. Yue X, Mehmet H, Penrice J, Cooper C, Cady E, Wyatt JS, et al. Apoptosis and necrosis in the newborn piglet brain following transient cerebral hypoxia-ischaemia. Neuropathol Appl Neurobiol 23:16-25, 1997.

46. Dell'Anna E, Chen Y, Engidawork E, Andersson K, Lubec G, Luthman J, et al. Delayed neuronal death following perinatal asphyxia in rat. Exp Brain Res 115:105-15, 1997.

47. Ishimaru MJ, Ikonomidou C, Tenkova TI, Der TC, Dikranian K, Sesma MA, et al. Distinguishing excitotoxic from apoptotic neurodegeneration in the developing rat brain. J Comp Neurol 408: 461-76, 1999.

48. Orrenius S, Zhivotovsky B, Nicotera P. Regulation of cell death: the calcium-apoptosis link. Nat Rev Mol Cell Biol 4:552-65, 2003.

49. Johnston MV. Excitotoxicity in perinatal brain injury. Brain Pathol 15:234-40, 2005.

50. Brown GC, Bal-Price A. Inflammatory neurodegeneration mediated by nitric oxide, glutamate, and mitochondria. Mol Neurobiol 27:325-55, 2003.

51. Taylor DL, Edwards AD, Mehmet H. Oxidative metabolism, apoptosis and perinatal brain injury. Brain Pathol 9:93-117, 1999.

52. MacGibbon GA, Lawlor PA, Sirimanne ES, Walton MR, Connor $B$, Young D, et al. Bax expression in mammalian neurons undergoing apoptosis, and in Alzheimer's disease hippocampus. Brain Res 750:223-234, 1997.

53. Zhu C, Wang X, Hagberg H, Blomgren K. Correlation between caspase- 3 activation and three different markers of DNA damage in neonatal cerebral hypoxia-ischemia. J Neurochem 75:819829,2000

54. Samejima K, Tone S, Kottke TJ, Enari M, Sakahira H, Cooke CA, et al. Transition from caspase-dependent to caspase-independent mechanisms at the onset of apoptotic execution. J Cell Biol 143:225-39, 1998.

55. Edwards AD, Yue X, Squier MV, Thoresen M, Cady EB, Penrice $\mathrm{J}$, et al. Specific inhibition of apoptosis after cerebral hypoxiaischaemia by moderate post-insult hypothermia. Biochem Biophys Res Commun 217:1193-1199, 1995.

56. Edwards AD, Yue X, Cox P, Hope PL, Azzopardi DV, Squier $\mathrm{MV}$, et al. Apoptosis in the brains of infants suffering intrauterine cerebral injury. Pediatr Res 42:684-689, 1997.
57. Scott RJ, Hegyi L. Cell death in perinatal hypoxic-ischaemic brain injury. Neuropathol Appl Neurobiol 23:307-14, 1997.

58. Gottron FJ, Ying HS, Choi DW. Caspase inhibition selectively reduces the apoptotic component of oxygen-glucose deprivationinduced cortical neuronal cell death. Mol Cell Neurosci 9:15969, 1997.

59. Portera-Cailliau C, Price DL, Martin LJ. Excitotoxic neuronal death in the immature brain is an apoptosis-necrosis morphological continuum. J Comp Neurol 378:70-87, 1997.

60. Du C, Hu R, Csernansky CA, Hsu CY, Choi DW. Very delayed infarction after mild focal cerebral ischemia: a role for apoptosis? J Cereb Blood Flow Metab 16:195-201, 1996.

61. Nakajima W, Ishida A, Lange MS, Gabrielson KL, Wilson MA, Martin LJ, et al. Apoptosis has a prolonged role in the neurodegeneration after hypoxic ischemia in the newborn rat. $J$ Neurosci 20:7994-8004, 2000.

62. Rothstein RP, Levison SW. Gray matter oligodendrocyte progenitors and neurons die caspase- 3 mediated deaths subsequent to mild perinatal hypoxic/ischemic insults. Dev Neurosci 27:149_ 59, 2005.

63. Edwards AD, Mehmet H. Apoptosis in perinatal hypoxic-ischaemic cerebral damage. Neuropathol Appl Neurobiol 22:494498, 1996.

64. Northington FJ, Ferriero DM, Flock DL, Martin LJ. Delayed neurodegeneration in neonatal rat thalamus after hypoxia-ischemia is apoptosis. $J$ Neurosci 21:1931-8, 2001.

65. Ness JK, Romanko MJ, Rothstein RP, Wood TL, Levison SW Perinatal hypoxia-ischemia induces apoptotic and excitotoxic death of periventricular white matter oligodendrocyte progenitors. Dev Neurosci 23:203-8, 2001.

66. Back SA, Luo NL, Borenstein NS, Levine JM, Volpe JJ, Kinney HC. Late oligodendrocyte progenitors coincide with the developmental window of vulnerability for human perinatal white matter injury. J Neurosci 21:1302-12, 2001.

67. Laptook AR, Corbett RJ, Sterett R, Burns DK, Garcia D, Tollefsbol G. Modest hypothermia provides partial neuroprotection when used for immediate resuscitation after brain ischemia. $P e$ diatr Res 42:17-23, 1997.

68. Haaland K, Loberg EM, Steen PA, Thoresen M. Posthypoxic hypothermia in newborn piglets. Pediatr Res 41:505-512, 1997.

69. Yager J, Towfighi J, Vannucci RC. Influence of mild hypothermia on hypoxic-ischemic brain damage in the immature rat. Pediatr Res 34:525-529, 1993.

70. Sirimanne ES, Blumberg RM, Bossano D, Gunning M, Edwards $\mathrm{AD}$, Gluckman PD, et al. The effect of prolonged modification of cerebral temperature on outcome after hypoxic-ischemic brain injury in the infant rat. Pediatr Res 39:591-597, 1996.

71. Thoresen M, Bagenholm R Loberg EM, Apricena F, Kjellmer I. Posthypoxic cooling of neonatal rats provides protection against brain injury. Arch Dis Child Fetal Neonatal Ed 74:F3-F9, 1996.

72. Laptook AR, Corbett RJ, Burns DK, Sterett R. A limited interval of delayed modest hypothermia for ischemic brain resuscitation is not beneficial in neonatal swine. Pediatr Res 46:383-389, 1999.

73. Shuaib A, Trulove D, Ijaz MS, Kanthan R, Kalra J. The effect of post-ischemic hypothermia following repetitive cerebral ischemia in gerbils. Neurosci Lett 186:165-168, 1995.

74. Busto R, Dietrich WD, Globus MY, Ginsberg MD. Postischemic moderate hypothermia inhibits CA1 hippocampal ischemic neuronal injury. Neurosci Lett 101:299-304, 1989.

75. Bona E, Hagberg H, Loberg EM, Bagenholm R, Thoresen M. Protective effects of moderate hypothermia after neonatal hypoxia- ischemia: short- and long-term outcome. Pediatr Res 43:738745, 1998.

76. Thoresen M, Penrice J, Lorek A, Cady EB, Wylezinska M, Kirkbride $\mathrm{V}$, et al. Mild hypothermia after severe transient hypoxiaischemia ameliorates delayed cerebral energy failure in the newborn piglet. Pediatr Res 37:667-670, 1995.

77. Tooley JR, Satas S, Porter H, Silver IA, Thoresen M. Head cooling with mild systemic hypothermia in anesthetized piglets is neuroprotective. Ann Neurol 53:65-72, 2003.

78. Gunn AJ, Bennet L. Hypothermia in the management of hypoxicischemic encephalopathy. NeoReviews 3:e116-e122, 2002. 
79. Gunn AJ, Gunn TR, Gunning MI, Williams CE, Gluckman PD. Neuroprotection with prolonged head cooling started before postischemic seizures in fetal sheep. Pediatrics 102:1098-1106, 1998.

80. Gunn AJ, Bennet L, Gunning MI, Gluckman PD, Gunn TR. Cerebral hypothermia is not neuroprotective when started after postischemic seizures in fetal sheep. Pediatr Res 46:274-280, 1999.

81. Gerrits LC, Battin MR, Bennet L, Gonzalez H, Gunn AJ. Epileptiform activity during rewarming from moderate cerebral hypothermia in the near-term fetal sheep. Pediatr Res 57:342-6, 2005.

82. Colbourne F, Corbett D. Delayed postischemic hypothermia: a six month survival study using behavioral and histological assessments of neuroprotection. J Neurosci 15:7250-7260, 1995.

83. Colbourne F, Li H, Buchan AM. Indefatigable CA1 sector neuroprotection with mild hypothermia induced 6 hours after severe forebrain ischemia in rats. $J$ Cereb Blood Flow Metab 19:742_ 749, 1999.

84. Colbourne F, Corbett D, Zhao Z, Yang J, Buchan AM. Prolonged but delayed postischemic hypothermia: a long-term outcome study in the rat middle cerebral artery occlusion model. J Cereb Blood Flow Metab 20:1702-1708, 2000.

85. Schubert A. Side effects of mild hypothermia. J Neurosurg Anesthesiol 7:139-47, 1995.

86. Weinrauch V, Safar P, Tisherman S, Kuboyama K, Radovsky A. Beneficial effect of mild hypothermia and detrimental effect of deep hypothermia after cardiac arrest in dogs. Stroke 23:145462, 1992.

87. Colbourne F, Auer RN, Sutherland GR. Characterization of postischemic behavioral deficits in gerbils with and without hypothermic neuroprotection. Brain Res 803:69-78, 1998.

88. Bernard SA, Gray TW, Buist MD, Jones BM, Silvester W, Gutteridge G, et al. Treatment of comatose survivors of out-ofhospital cardiac arrest with induced hypothermia. $N$ Engl $\mathrm{J}$ Med 346:557-563, 2002

89. The Hypothermia after Cardiac Arrest Study Group. Mild therapeutic hypothermia to improve the neurologic outcome after cardiac arrest. N Engl J Med 346:549-556, 2002.

90. Dietrich WD, Busto R, Alonso O, Globus MY, Ginsberg MD. Intraischemic but not postischemic brain hypothermia protects chronically following global forebrain ischemia in rats. $J$ Cereb Blood Flow Metab 13:541-549, 1993.

91. Nurse S, Corbett D. Neuroprotection after several days of mild, drug-induced hypothermia. J Cereb Blood Flow Metab 16:474480, 1996

92. Coimbra C, Drake M, Boris-Moller F, Wieloch T. Long-lasting neuroprotective effect of postischemic hypothermia and treatment with an anti-inflammatory/antipyretic drug. Evidence for chronic encephalopathic processes following ischemia. Stroke 27:1578$1585,1996$.

93. Trescher WH, Ishiwa S, Johnston MV. Brief post-hypoxic-ischemic hypothermia markedly delays neonatal brain injury. Brain Dev 19:326-338, 1997.

94. Nedelcu J, Klein MA, Aguzzi A, Martin E. Resuscitative hypothermia protects the neonatal rat brain from hypoxic- ischemic injury. Brain Pathol 10:61-71, 2000.

95. Wagner BP, Nedelcu J, Martin E. Delayed postischemic hypothermia improves long-term behavioral outcome after cerebral hypoxia-ischemia in neonatal rats. Pediatr Res 51:354-360, 2002.

96. Corbett D, Hamilton M, Colbourne F. Persistent neuroprotection with prolonged postischemic hypothermia in adult rats subjected to transient middle cerebral artery occlusion. Exp Neurol 163: 200-206, 2000.

97. Colbourne F, Sutherland G, Corbett D. Postischemic hypothermia. A critical appraisal with implications for clinical treatment. Mol Neurobiol 14:171-201, 1997.

98. Laptook AR, Corbett RJ, Sterett R, Garcia D, Tollefsbol G. Quantitative relationship between brain temperature and energy utilization rate measured in vivo using $31 \mathrm{P}$ and $1 \mathrm{H}$ magnetic resonance spectroscopy. Pediatr Res 38:919-925, 1995.

99. Erecinska M, Thoresen M, Silver IA. Effects of hypothermia on energy metabolism in Mammalian central nervous system. J Cereb Blood Flow Metab 23:513-30, 2003.

100. Bart RD, Takaoka S, Pearlstein RD, Dexter F, Warner DS. Interactions between hypothermia and the latency to ischemic depolarization: implications for neuroprotection. Anesthesiology 88: 1266-1273, 1998.

101. Nakashima K, Todd MM. Effects of hypothermia on the rate of excitatory amino acid release after ischemic depolarization. Stroke 27:913-918, 1996.

102. Thoresen M, Satas S, Puka-Sundvall M, Whitelaw A, Hallstrom A, Loberg EM, et al. Post-hypoxic hypothermia reduces cerebrocortical release of NO and excitotoxins. Neuroreport 8:33593362, 1997.

103. Lei B, Adachi N, Arai T. The effect of hypothermia on $\mathrm{H} 2 \mathrm{O} 2$ production during ischemia and reperfusion: a microdialysis study in the gerbil hippocampus. Neurosci Lett 222:91-94, 1997.

104. Kristian T, Katsura K, Siesjo BK. The influence of moderate hypothermia on cellular calcium uptake in complete ischaemia: implications for the excitotoxic hypothesis. Acta Physiol Scand 146:531-2, 1992.

105. Bruno VM, Goldberg MP, Dugan LL, Giffard RG, Choi DW. Neuroprotective effect of hypothermia in cortical cultures exposed to oxygen-glucose deprivation or excitatory amino acids. J Neurochem 63:1398-406, 1994.

106. Xu RX, Nakamura T, Nagao S, Miyamoto O, Jin L, Toyoshima $\mathrm{T}$, et al. Specific inhibition of apoptosis after cold-induced brain injury by moderate postinjury hypothermia. Neurosurgery 43 : 107-114, 1998.

107. Inamasu J, Suga S, Sato S, Horiguchi T, Akaji K, Mayanagi K, et al. Postischemic hypothermia attenuates apoptotic cell death in transient focal ischemia in rats. Acta Neurochir Suppl 76:525$527,2000$.

108. Colbourne F, Sutherland GR, Auer RN. Electron microscopic evidence against apoptosis as the mechanism of neuronal death in global ischemia. J Neurosci 19:4200-4210, 1999.

109. Hu BR, Liu CL, Ouyang Y, Blomgren K, Siesjo BK. Involvement of caspase-3 in cell death after hypoxia-ischemia declines during brain maturation. J Cereb Blood Flow Metab 20:1294-1300, 2000.

110. Johnson MD, Kinoshita Y, Xiang H, Ghatan S, Morrison RS. Contribution of p53-dependent caspase activation to neuronal cell death declines with neuronal maturation. J Neurosci 19:29963006, 1999.

111. Zhu C, Qiu L, Wang X, Hallin U, Cande C, Kroemer G, et al. Involvement of apoptosis-inducing factor in neuronal death after hypoxia-ischemia in the neonatal rat brain. J Neurochem 86:30617, 2003.

112. Roelfsema V, Bennet L, George S, Wu D, Guan J, Veerman M, et al. The window of opportunity for cerebral hypothermia and white matter injury after cerebral ischemia in near-term fetal sheep. J Cereb Blood Flow Metab 24:877-886, 2004.

113. Bossenmeyer-Pourie C, Koziel V, Daval JL. Effects of hypothermia on hypoxia-induced apoptosis in cultured neurons from developing rat forebrain: comparison with preconditioning. Pediatr Res 47:385-391, 2000.

114. Si QS, Nakamura Y, Kataoka K. Hypothermic suppression of microglial activation in culture: inhibition of cell proliferation and production of nitric oxide and superoxide. Neuroscience 81 : 223-229, 1997.

115. Goss JR, Styren SD, Miller PD, Kochanek PM, Palmer AM, Marion DW, et al. Hypothermia attenuates the normal increase in interleukin 1 beta RNA and nerve growth factor following traumatic brain injury in the rat. J Neurotrauma 12:159-167, 1995.

116. Chatzipanteli K, Alonso OF, Kraydieh S, Dietrich WD. Importance of posttraumatic hypothermia and hyperthermia on the inflammatory response after fluid percussion brain injury: biochemical and immunocytochemical studies. J Cereb Blood Flow Metab 20:531-542, 2000.

117. Inamasu J, Suga S, Sato S, Horiguchi T, Akaji K, Mayanagi K, et al. Post-ischemic hypothermia delayed neutrophil accumulation and microglial activation following transient focal ischemia in rats. J Neuroimmunol. 109:66-74, 2000.

118. Levin S, Godukhin O. Developmental changes in hyperexcitabil- 
ity of CA1 pyramidal neurons induced by repeated brief episodes of hypoxia in the rat hippocampal slices. Neurosci Lett 377:20-4, 2005.

119. Zanelli SA, Numagami Y, McGowan JE, Mishra OP, DelivoriaPapadopoulos M. NMDA receptor-mediated calcium influx in cerebral cortical synaptosomes of the hypoxic guinea pig fetus. Neurochem Res 24:437-46, 1999.

120. Mitani A, Namba S, Ikemune K, Yanase H, Arai T, Kataoka K. Postischemic enhancements of N-methyl-D-aspartic acid (NMDA) and non-NMDA receptor-mediated responses in hippocampal CA1 pyramidal neurons. J Cereb Blood Flow Metab 18:1088-98, 1998.

121. Jensen FE, Wang C, Stafstrom CE, Liu Z, Geary C, Stevens MC. Acute and chronic increases in excitability in rat hippocampal slices after perinatal hypoxia In vivo. J Neurophysiol 79:73-81, 1998.

122. Hossmann KA. Periinfarct depolarizations. Cerebrovasc Brain Metab Rev 8:195-208, 1996.

123. Busch E, Gyngell ML, Eis M, Hoehn-Berlage M, Hossmann KA. Potassium-induced cortical spreading depressions during focal cerebral ischemia in rats: contribution to lesion growth assessed by diffusion-weighted NMR and biochemical imaging. J Cereb Blood Flow Metab 16:1090-9, 1996.

124. Baldwin M, Frost LL. Effect of hypothermia on epileptiform activity in the primate temporal lobe. Science 124:931-2, 1956.

125. Karkar KM, Garcia PA, Bateman LM, Smyth MD, Barbaro NM, Berger M. Focal cooling suppresses spontaneous epileptiform activity without changing the cortical motor threshold. Epilepsia 43:932-935, 2002.

126. Gunn AJ, Gluckman PD, Gunn TR. Selective head cooling in newborn infants after perinatal asphyxia: a safety study. Pediatrics 102:885-892, 1998.

127. Battin MR, Dezoete JA, Gunn TR, Gluckman PD, Gunn AJ. Neurodevelopmental outcome of infants treated with head cooling and mild hypothermia after perinatal asphyxia. Pediatrics 107:480-484, 2001.

128. Battin MR, Penrice J, Gunn TR, Gunn AJ. Treatment of term infants with head cooling and mild systemic hypothermia (35.0 degrees $\mathrm{C}$ and 34.5 degrees $\mathrm{C}$ ) after perinatal asphyxia. Pediatrics 111:244-251, 2003.

129. Akisu M, Huseyinov A, Yalaz M, Cetin H, Kultursay N. Selective head cooling with hypothermia suppresses the generation of platelet-activating factor in cerebrospinal fluid of newborn infants with perinatal asphyxia. Prostaglandins Leukot Essent Fatty Acids 69:45-50, 2003.

130. Shankaran S, Laptook A, Wright LL, Ehrenkranz RA, Donovan EF, Fanaroff AA, et al. Whole-body hypothermia for neonatal encephalopathy: animal observations as a basis for a randomized, controlled pilot study in term infants. Pediatrics 110:377-385, 2002.

131. Thoresen M, Whitelaw A. Cardiovascular changes during mild therapeutic hypothermia and rewarming in infants with hypoxicischaemic encephalopathy. Pediatrics 106:92-99, 2000.

132. Azzopardi D, Robertson NJ, Cowan FM, Rutherford MA, Rampling M, Edwards AD. Pilot study of treatment with whole body hypothermia for neonatal encephalopathy. Pediatrics 106:684694, 2000.

133. Debillon T, Daoud P, Durand P, Cantagrel S, Jouvet P, Saizou C, et al. Whole-body cooling after perinatal asphyxia: a pilot study in term neonates. Dev Med Child Neurol 45:17-23, 2003.

134. Compagnoni G, Pogliani L, Lista G, Castoldi F, Fontana P, Mosca F. Hypothermia reduces neurological damage in asphyxiated newborn infants. Biol Neonate 82:222-227, 2002.

135. Zhou WH, Shao XM, Cao Y, Chen C, Zhang XD. Safety study of hypothermia for treatment of hypoxic-ischemic brain damage in term neonates. Acta Pharmacol Sin 23:64-68, 2003.

136. Eicher DJ, Wagner CL, Katikaneni LP, Hulsey TC, Bass WT, Kaufman DA, et al. Moderate hypothermia in neonatal encephalopathy: Safety outcomes. Pediatr Neurol 32:18-24, 2005.

137. Eicher DJ, Wagner CL, Katikaneni LP, Hulsey TC, Bass WT, Kaufman DA, et al. Moderate hypothermia in neonatal encephalopathy: Efficacy outcomes. Pediatr Neurol 32:11-7, 2005.

138. Gluckman PD, Wyatt JS, Azzopardi D, Ballard D, Edwards AD,
Ferriero DM, et al. Selective head cooling with mild systemic hypothermia to improve neurodevelopmental outcome following neonatal encephalopathy. Lancet 365:663-670, 2005.

139. Gunn AJ, Gluckman PD, Wyatt JS, Thoresen M, Edwards AD. Selective head cooling after neonatal encephalopathy. Lancet 365:1619-1620, 2005.

140. Kendrick JE, Turner KA. Carotid sinus depressor reflexes during hypothermia. Am J Physiol 207:777-81, 1964.

141. Shankaran S, Laptook AR, Ehrenkranz RA, Tyson JE, McDonald SA, Donovan EF, et al. Whole-body hypothermia for neonates with hypoxic-ischemic encephalopathy. N Engl J Med 353:157484, 2005.

142. Inder TE, Hunt RW, Morley CJ, Coleman L, Stewart M, Doyle LW, et al. Randomized trial of systemic hypothermia selectively protects the cortex on MRI in term hypoxic-ischemic encephalopathy. J Pediatr 145:835-7, 2004.

143. Rutherford MA, Azzopardi D, Whitelaw A, Cowan F, Renowden $\mathrm{S}$, Edwards AD, et al. Mild hypothermia and the distribution of cerebral lesions in neonates with hypoxic-ischemic encephalopathy. Pediatrics 116:1001-6, 2005.

144. Westgate JA, Gunn AJ, Gunn TR. Antecedents of neonatal encephalopathy with fetal acidaemia at term. Br J Obstet Gynaecol 106:774-782, 1999.

145. Cowan F, Rutherford M, Groenendaal F, Eken P, Mercuri E, Bydder GM, et al. Origin and timing of brain lesions in term infants with neonatal encephalopathy. Lancet 361:736-42, 2003.

146. Geddes R, Vannucci RC, Vannucci SJ. Delayed cerebral atrophy following moderate hypoxia-ischemia in the immature rat. Dev Neurosci 23:180-185, 2001.

147. Sarnat HB, Sarnat MS. Neonatal encephalopathy following fetal distress. A clinical and electroencephalographic study. Arch Neurol 33:696-705, 1976.

148. Wass CT, Waggoner JR, Cable DG, Schaff HV, Schroeder DR, Lanier WL. Selective convective brain cooling during normothermic cardiopulmonary bypass in dogs. J Thorac Cardiovasc Surg 115:1350-1357, 1998.

149. Simbruner G, Haberl C, Harrison V, Linley L, Willeitner AE. Induced brain hypothermia in asphyxiated human newborn infants: a retrospective chart analysis of physiological and adverse effects. Intensive Care Med 25:1111-1117, 1999.

150. Laptook AR, Shalak L, Corbett RJ. Differences in brain temperature and cerebral blood flow during selective head versus wholebody cooling. Pediatrics 108:1103-10, 2001.

151. Thoresen M, Simmonds M, Satas S, Tooley J, Silver I. Effective selective head cooling during posthyoxic hypothermia in newborn piglets. Pediatr Res 49:594-599, 2001.

152. Tooley J, Satas S, Eagle R, Silver IA, Thoresen M. Significant selective head cooling can be maintained long-term after global hypoxia ischemia in newborn piglets. Pediatrics 109:643-649, 2002.

153. Tooley JR, Eagle RC, Satas S, Thoresen M. Significant head cooling can be achieved while maintaining normothermia in the newborn piglet. Arch Dis Child Fetal Neonatal Ed 90:F262-6, 2005.

154. Iwata O, Thornton JS, Sellwood MW, Iwata S, Sakata Y, Noone MA, et al. Depth of delayed cooling alters neuroprotection pattern after hypoxia-ischemia. Ann Neurol 58:75-87, 2005.

155. Battin MR, Bennet L, Gunn AJ. Rebound seizures during rewarming. Pediatrics 114:1369, 2004.

156. Nakamura T, Miyamoto O, Sumitani K, Negi T, Itano T, Nagao $\mathrm{S}$. Do rapid systemic changes of brain temperature have an influence on the brain? Acta Neurochir (Wien) 145:301-7, 2003.

157. Suehiro E, Povlishock JT. Exacerbation of traumatically induced axonal injury by rapid posthypothermic rewarming and attenuation of axonal change by cyclosporin A. J Neurosurg 94:493-8, 2001.

158. Ueda Y, Suehiro E, Wei EP, Kontos HA, Povlishock JT. Uncomplicated rapid posthypothermic rewarming alters cerebrovascular responsiveness. Stroke 35:601-6, 2004.

159. Gunn AJ. Cerebral hypothermia for prevention of brain injury following perinatal asphyxia. Curr Opin Pediatr 12:111-115, 2000. 
160. Todd MM, Hindman BJ, Clarke WR, Torner JC. Mild intraoperative hypothermia during surgery for intracranial aneurysm. N Engl J Med 352:135-45, 2005.

161. Satas S, Loberg EM, Porter H, Whitelaw A, Steen PA, Thoresen M. Effect of global hypoxia-ischaemia followed by $24 \mathrm{~h}$ of mild hypothermia on organ pathology and biochemistry in a newborn pig survival model. Biol Neonate 83:146-56, 2003.

162. Gordon CJ, Heath JE. Integration and central processing in temperature regulation. Annu Rev Physiol 48:595-612:595-612, 1986.

163. Gunn TR, Wilson NJ, Aftimos S, Gunn AJ. Brain hypothermia and QT interval. Pediatrics 103:1079, 1999.

164. Green EJ, Pazos AJ, Dietrich WD, McCabe PM, Schneiderman $\mathrm{N}$, Lin B, et al. Combined postischemic hypothermia and delayed MK-801 treatment attenuates neurobehavioral deficits associated with transient global ischemia in rats. Brain Res 702:145-152, 1995.

165. Ikonomidou C, Mosinger JL, Olney JW. Hypothermia enhances protective effect of MK-801 against hypoxic/ischemic brain damage in infant rats. Brain Res 487:184-7, 1989.

166. Alkan T, Kahveci N, Buyukuysal L, Korfali E, Ozluk K. Neuroprotective effects of MK 801 and hypothermia used alone and in combination in hypoxic-ischemic brain injury in neonatal rats. Arch Physiol Biochem 109:135-144, 2001.

167. Ma D, Hossain M, Chow A, Arshad M, Battson RM, Sanders RD, et al. Xenon and hypothermia combine to provide neuroprotection from neonatal asphyxia. Ann Neurol 58:182-93, 2005.

168. Thoresen M, Satas S, Loberg EM, Whitelaw A, Acolet D, Lindgren $\mathrm{C}$, et al. Twenty-four hours of mild hypothermia in unsedated newborn pigs starting after a severe global hypoxicischemic insult is not neuroprotective. Pediatr Res 50:405-411, 2001.

169. Colbourne F, Li H, Buchan AM, Clemens JA. Continuing postischemic neuronal death in CA1: influence of ischemia duration and cytoprotective doses of NBQX and SNX-111 in rats. Stroke 30:662-668, 1999.

170. Liu Y, Barks JD, Xu G, Silverstein FS. Topiramate extends the therapeutic window for hypothermia-mediated neuroprotection after stroke in neonatal rats. Stroke 35:1460-5, 2004.

171. Guan J, Gunn AJ, Sirimanne ES, Tuffin J, Gunning MI, Clark R, et al. The window of opportunity for neuronal rescue with insulinlike growth factor-1 after hypoxia-ischemia in rats is critically modulated by cerebral temperature during recovery. J Cereb Blood Flow Metab 20:513-519, 2000.

172. Meldrum B, Garthwaite J. Excitatory amino acid neurotoxicity and neurodegenerative disease. Trends Pharmacol Sci 11:37987, 1990.

173. Bear MF, Kleinschmidt A, Gu QA, Singer W. Disruption of experience-dependent synaptic modifications in striate cortex by infusion of an NMDA receptor antagonist. J Neurosci 10:909-25, 1990.

174. Brosnan-Watters G, Wozniak DF, Nardi A, Olney JW. Parallel recovery of MK-801-induced spatial learning impairment and neuronal injury in male mice. Pharmacol Biochem Behav 62: 111-22, 1999.

175. Facchinetti F, Ciani E, Dall'Olio R, Virgili M, Contestabile A, Fonnum F. Structural, neurochemical and behavioural consequences of neonatal blockade of NMDA receptor through chronic treatment with CGP 39551 or MK-801. Brain Res Dev Brain Res 74:219-24, 1993.

176. Ikonomidou C, Bosch F, Miksa M, Bittigau P, Vockler J, Dikranian K, et al. Blockade of NMDA receptors and apoptotic neurodegeneration in the developing brain. Science 283:70-4, 1999

177. Pohl D, Bittigau P, Ishimaru MJ, Stadthaus D, Hubner C, Olney JW, et al. N-Methyl-D-aspartate antagonists and apoptotic cell death triggered by head trauma in developing rat brain. Proc Natl Acad Sci U S A 96:2508-13, 1999. 